\title{
Isoquinoline Alkaloid Berberine Exerts its Antineoplastic Activity by Inducing Molecular DNA Damage in HeLa Cells: A Comet Assay Study
}

Ganesh Chandra Jagetia ${ }^{1^{*}}$ and Rao ${ }^{2}$

${ }^{1}$ Department of Zoology, Mizoram University, Aizawl-796 004, India

${ }^{2}$ Department of Pharmacognosy, C. U. Shah College of Pharmacy \& Research, Wadhwan, India

*Corresponding author: Ganesh Chandra Jagetia, Department of Zoology, Mizoram University, Aizawl-796 004, India, Tel: 91-0389-233051; Fax: 91-0389-2330227; Email: gc.jagetia@gmail.com

Received date: August 25, 2014, Accepted date: December 24, 2014, Published date: January 2, 2015

Copyright: ( 2015 Jagetia GC, et al. This is an open-access article distributed under the terms of the Creative Commons Attribution License, which permits unrestricted use, distribution, and reproduction in any medium, provided the original author and source are credited

Short Title: Berberine acts by damaging DNA in HeLa cells

\begin{abstract}
Molecular damage of DNA plays an important role in the cell killing and several anti-neoplastic agents exert their cytotoxic effects by inducing DNA damage in the cancer cells. DNA damaging effect of various concentrations of berberine chloride (BCL), an isoquinoline alkaloid was studied in HeLa cells by alkaline comet assay. The DNA damage has been expressed as olive tail moment (OTM). Incubation of HeLa cells with BCL for $4 \mathrm{~h}$ showed greater amount of DNA damage (OTM) than $2 \mathrm{~h}$ treatment. BCL treatment caused a concentration dependent rise in the DNA damage in HeLa cells and exposure of HeLa cells with $1 \mu \mathrm{g} / \mathrm{ml} \mathrm{BCL}$ caused a10 fold rise in baseline DNA damage, whereasa maximum rise in DNA damage was observed in HeLa cells exposed to $8 \mu \mathrm{g} / \mathrm{ml} \mathrm{BCL}$. The study of DNA repair kinetics at different BCL post-treatment times revealed a constant rise in the DNA damage in BCL treated cells up to $24 \mathrm{~h}$ except for $1-4 \mu \mathrm{g} / \mathrm{ml} \mathrm{BCL}$, where the highest DNA damage was observed at $12 \mathrm{~h}$ post-BCL treatment. The clonogenic assay showed that $B C L$ treatment resulted in a concentration dependent rise in its cell killing effect. The cell survival and molecular DNA damage in HeLa cells treated with BCL has an inverse correlation indicating that with increased DNA damage cell survival declined. Our study demonstrates that anti-neoplastic effect of $B C L$ is mainly due to its ability to cause damage to the cellular genome.
\end{abstract}

Keywords: Berberine; HeLa cells; Comet assay; DNA damage; Cell survival

\section{Introduction}

Plants and herbs have attracted the attention of humans for their healthcare since the advent of human history. The sophisticated traditional systems of medicine, especially from India and China extensively use plants and herbs for human healthcare and these systems of medicine have documented the use of various plants derived and/or natural products for medicinal use. The plant-based systems continue to play an important role in human healthcare and it has been estimated by World Health Organization that approximately $80 \%$ of the world's inhabitants rely mainly on traditional systems for their primary healthcare [1]. The botanicals have provided many important generic molecules that have been used in the treatment of several human diseases including cancer in modern medicine [2].

DNA damage plays a pivotal role in most mechanisms underlying the action of anticancer drugs that interact with DNA and subsequently kill neoplastic cells. Therefore it is necessary to understand the DNA damaging effects of various antineoplastic agents on normal and cancer cells [3]. The comet assay determines the amount of DNA damage (both single and double strand breaks and conformational changes) in a cell exposed to DNA damaging agents. The single cell gel electrophoresis or comet assay was first designed by Östling and Johanson [4] to estimate the DNA damage in the single cells. Since then it has been modified by various workers to estimate various types of DNA damage [5-7]. The alkaline comet assay is simple and allows the measurement of DNA damage and repair in the individual cells and hence it is widely used to estimate the DNA damage or DNA repair in various settings [5,6]. It has been employed in biomonitoring, assessment of genotoxicity, and response to tumor therapy in clinical or preclinical settings [5,7]. The DNA damage in this assay is measured from the chromatid fragments migrating out of the nucleus in a cell and forming comet like structures [5-7].

Berberine containing plants are used medicinally in virtually all traditional medical systems, and have a long history of usage in Ayurvedic and Chinese systems of medicine, dating back to at least 5,000 years[8]. Berberine is an isoquinoline alkaloid present in the roots, rhizomes, and stem bark of a number of clinically important medicinal plants including Hydrastis canadensis (goldenseal), Coptis chinensis (coptis or golden thread), Berberis aquifolium (Oregon grape), Berberis aristata (tree turmeric) and Tinospora cordifolia (guduchi or giloe) $[9,10]$. The giloe has been reported to be cytotoxic in HeLa cells and this cytotoxic effect was due to its ability to induce DNA damage [11-13]. Berberine has been reported to possess antibacterial, anti-diarrheal, anti-arrhythmic, anti-inflammatory, antidiabetic, anti-arthrogenic and anticancer activities [11-19]. It has been also reported to be active in Alzheimer's disease [20]. Berberine has been found to suppress angiogenesis and hypoxia inducible factor [21]. Clinical trials have indicated that berberine has been effective in improving the cardiac performance in patients with heart failure. It exerts direct depressive action on myocardial vasculature and smooth musculature [22] and may have anti-cholesterolase activity [23]. Recent clinical trials have shown that berberine has potential as a safe oral hypoglycemic agent to treat type II diabetes in patients with dyslipidemia [24]. Berberine sulfate has been reported to significantly inhibit the tumor yield and incidence of tumor-bearing animals in two 
stage skin carcinogenesis induced by 7,12-dimethylbenz(a) anthracene (DMBA) and promoted with teleocidin [25]. An earlier study has reported the anticancer activity of berberine chloride in vivo in mice transplanted with Ehrlich ascites carcinoma [18]. However, it is necessary to investigate the cytotoxicity in different study systems and how this action is mediated? Therefore, the present study was undertaken to obtain an insight into the DNA damaging effects of BCL by alkaline comet assay and its correlation with cell survival in HeLa cells.

\section{Materials and Methods}

\section{Chemicals and reagents}

Berberine chloride (BCL), Minimum Essential Medium (MEM), Lglutamine, gentamicin sulfate, fetal calf serum, normal and low melting agarose (Cat No. A-4718), ethylene diamine tertra acetic acid (EDTA), trizama base, ethidium bromide and triton X-100 were procured from Sigma Chemical Co. St. Louis, USA. Other routine chemicals were procured from Ranbaxy fine Chemicals, Mumbai, India

\section{Preparation of drug}

Berberine chloride was freshly dissolved immediately before use in sterile double distilled water (DDW) at a concentration of $5 \mathrm{mg} / \mathrm{ml}$, filter sterilized and diluted in sterile MEM in such a way so as to obtain the required concentration.

\section{Cell line and culture}

HeLa S3 cells procured from National Centre for Cell Science, Pune, India were used throughout the study. The HeLa S3 cells have a doubling time of $20 \pm 2 \mathrm{~h}$. The cells were routinely grown in $25 \mathrm{~cm}^{2}$ culture flasks (Cellstar, Greiner, Germany) with loosened caps containing Eagle's minimum essential medium (MEM) supplemented with $10 \%$ fetal calf serum, $1 \% \mathrm{~L}$-glutamine and $50 \mu \mathrm{g} / \mathrm{ml}$ gentamicin sulfate at $37^{\circ} \mathrm{C}$ in an atmosphere of $5 \% \mathrm{CO}_{2}$ in humidified air in a $\mathrm{CO}_{2}$ incubator (NuAir, Plymouth, USA).

\section{Experimental Design}

A fixed number $\left(5 \times 10^{5}\right)$ of exponentially growing cells were inoculated into several culture flasks (Techno Plastic Products, Trasadingën, Switzerland). The cell cultures or cells impregnated in agarose (details are given in comet assay section) were divided into the following groups according to the treatment:

MEM: The cells of this group were cultured in minimum essential medium.

The cell cultures of this group were treated with $1,2,4,6$ or $8 \mu \mathrm{g} / \mathrm{ml}$ of BCL.

\section{Selection of optimum treatment duration}

A separate experiment was conducted to select the optimum treatment time of $\mathrm{BCL}$, where grouping and other conditions were essentially similar to that described above except that the HeLa cells impregnated in agarose of either group were treated with $0,1,2,4,6$ or $8 \mu \mathrm{g} / \mathrm{ml}$ of BCL for two or four hours before assessment of the DNA damage.

\section{DNA damage repair}

The grouping and other conditions were essentially same as described for selection of optimum time except that the HeLa cells set in agarose were treated with $0,1,2,4,6$ or $8 \mu \mathrm{g} / \mathrm{ml}$ of BCL for $4 \mathrm{~h}$. The BCL containing growth medium was replaced with the drug free medium and the HeLa cells embedded in agarose were incubated in the growth medium for $0,0.25,0.5,1,2,4,6,10,12,16,18$ and $24 \mathrm{~h}$ at $37^{\circ} \mathrm{C}$ before placing them into lysis buffer to study the repair kinetics of damaged DNA except for those slides that were assessed immediately (0h) for DNA damage.

\section{Clonogenic assay}

A separate experiment was performed to determine the cell survival after BCL treatment, where grouping and other conditions were essentially similar as described in experimental design section. The cell survival was determined by clonogenic assay as described earlier [26]. Briefly, the cells were harvested by trypsin EDTA treatment and 200 cells were inoculated into several individual culture dishes (Cellstar, Greiner, Germany) containing $5 \mathrm{ml}$ drug-free medium in triplicate for each drug dose for each group. The cells were treated with $0,1,2,4,6$ or $8 \mu \mathrm{g} \mathrm{ml} \mathrm{BCL}$ for $4 \mathrm{~h}$, respectively. The cells were allowed to grow for 11 days. The resultant colonies were stained with 1 percent crystal violet in methanol and clusters containing 50 or more cells were scored as a colony. The plating efficiency of cells was determined and the surviving fraction was fitted on to a linear quadratic model $\mathrm{SF}=\exp ^{-(\alpha \mathrm{D}+\mathrm{BD} 2)}$

\section{Alkalinecomet assay}

The DNA damage for both experiments was assessed by alkaline comet assay as described earlier [27]. The comet assay is based on embedding of cells in agarose, their lyses in alkaline buffer and application of an electric current, which pulls the charged DNA from the nucleus so that relaxed and broken DNA fragments migrate away from the nucleus than intact DNA. The resulting images, named for their appearance as cometsare measured to determine the extent of DNA lesion [5-7,28,29]. HeLa cells impregnated in agarose on microscope slides were treated or not with BCL either for 2 and $4 \mathrm{~h}$ (optimum time) or $4 \mathrm{~h}$ (DNA repair kinetics). Briefly, slides frosted at one side were covered with $100 \mu \mathrm{l}$ of $0.6 \%$ low melting agarose prepared in $\mathrm{Ca}^{2+}$ and $\mathrm{Mg}^{2+}$ free $\mathrm{PBS}$ at $37^{\circ} \mathrm{C}$ and the agarose was allowed to solidify under a cover slip on ice after which the cover slips were removed. Aliquots of $1 \mathrm{ml}$ containing $1 \times 10^{5}$ harvested HeLa cells in culture medium were centrifuged at $1,500 \mathrm{rpm}$ for $5 \mathrm{~min}$. The pelleted cells were resuspended in $80 \mu \mathrm{l}$ of $0.6 \%$ low melting agarose layered on to the first layer and allowed to solidify under a cover slip on ice. For repair slides, equal volumes of cell suspension (in MEM) and $1.2 \%$ LMA (dissolved in MEM) were mixed, layered and allowed to solidify under a fresh cover slip on ice. All the steps described above were conducted under a reduced light to avoid additional DNA damage.

The slides embedded with cells, were placed into cold lysis buffer containing $2.5 \mathrm{M} \mathrm{NaCl}, 100 \mathrm{mM} \mathrm{Na} \mathrm{a}_{2}$ EDTA, $10 \mathrm{~m}$ MTrizma base, $\mathrm{pH}$ 10 and $1 \%$ Triton X-100 (added afresh) to solubilize cellular proteins leaving DNA as nucleoids for $2 \mathrm{~h}$. After cell lysis, the slides were drained of lysis buffer and placed into a horizontal gel electrophoresis tank filled with fresh electrophoresis buffer containing $300 \mathrm{mMNaOH}$, $1 \mathrm{mM}$ Na2EDTA, pH 13, to a level of $\sim 0.25 \mathrm{~cm}$ above the slides. The slides were kept in the buffer for 20 min to allow DNA unwinding and 
Citation: Jagetia GC, Rao (2015) Isoquinoline Alkaloid Berberine Exerts its Antineoplastic Activity by Inducing Molecular DNA Damage in HeLa Cells: A Comet Assay Study . Biol Med (Aligarh) 7: 223. doi:10.4172/0974-8369.1000223

Page 3 of 7

electrophoresis was carried out for $20 \mathrm{~min}$ at $1.25 \mathrm{~V} \mathrm{~cm}^{-1}$ and $300 \mathrm{~mA}$ in cold. The slides were drained and flooded slowly with three changes of neutralization buffer (0.4 M Trizma base, $\mathrm{pH} 7.5)$ for 5 min each and were subsequently stained with $50 \mu$ l of ethidium bromide $(2$ $\mathrm{mg} / \mathrm{ml}$ ) and covered with a cover slip for immediate analysis. Ethidium bromide stained DNA on each slide was visualized at $40 \mathrm{X}$ magnification using fluorescence microscopy as "comets" with a fluorescent head and a tail (Figure 1).

The comet images were captured using an epi fluorescence microscope (Olympus BX51, Olympus Microscopes, Tokyo, Japan) equipped with a $515-535 \mathrm{~nm}$ excitation filter, a $590 \mathrm{~nm}$ barrier filter, and a CCD camera (CoolSNAP-Pro ${ }_{\mathrm{cf}}$ Digital Color Camera Kit Ver 4.1, Media Cybergenetics, Silver Spring, Maryland, USA). A total of 100 cells per slide were analyzed to give a representative result for the population of cells [29].
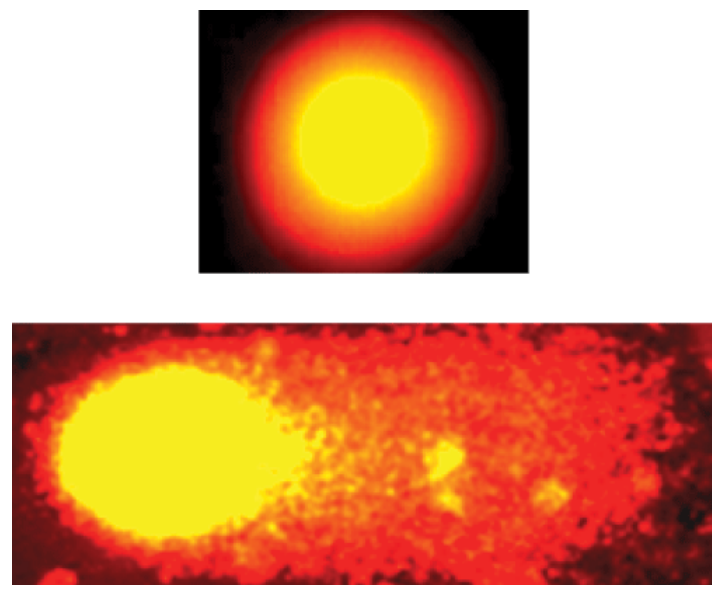

Figure 1: Representative comet images of HeLa cells treated or not with $8 \mu \mathrm{g} / \mathrm{ml}$ berberine chloride. Upper Panel: Untreated and Lower Panel:8 $\mu \mathrm{g} / \mathrm{ml}$ berberine chloride.

The comets images thus captured were analyzed using Komet software (Version 5.5, Kinetic Imaging Ltd, Bromborough, UK). The mean olive tail moment (OTM) was selected as the parameter that best reflects DNA damage (defined as the distance between the profile centres of gravity for DNA in the head and tail). OTM was measured from three independent experiments, each containing quintuplicate measures and presented as Mean \pm SEM (Standard error of mean).

\section{Statistical Analysis}

The statistical analyses were carried out using GraphPad Prism 2.01 statistical software (GraphPad Software, San Diego, CA, USA). The significance among all groups was determined by one-way ANOVA and Bonferroni's post-hoc test was applied for multiple comparisons. The experiments were repeated for confirmation of the results. The results are the average of five individual experiments. The test of homogeneity was applied to find out variation among each experiment. The data of each experiment did not differ significantly from one another and hence, all the data have been combined and means calculated. A p value of $<0.05$ was considered statistically significant.

\section{Results}

\section{Effect of treatment time}

Treatment of HeLa cells with different concentrations of BCL increased DNA damage significantly $(\mathrm{p}<0.0001)$ at $2 \mathrm{~h}$ post-BCL treatment and the maximum DNA damage was recorded for $8 \mu \mathrm{g} / \mathrm{ml}$ BCL. Incubation of HeLa cells with BCL for $4 \mathrm{~h}$ increased the DNA damage further when compared with $2 \mathrm{~h} \mathrm{BCL}$ treatment (Figure 2). Since a greater DNA damage was observed for $4 \mathrm{~h}$ BCL treatment, further studies were conducted using this BCL treatment time.

A further increase in BCL concentration resulted in a dose related rise in the DNA damage and the greatest damage was observed for 8 $\mu \mathrm{g} / \mathrm{ml}$ BCL. The DNA damage increased significantly when comparisons were made amongst various concentrations of BCL $(\mathrm{p}<$ $0.001)$.

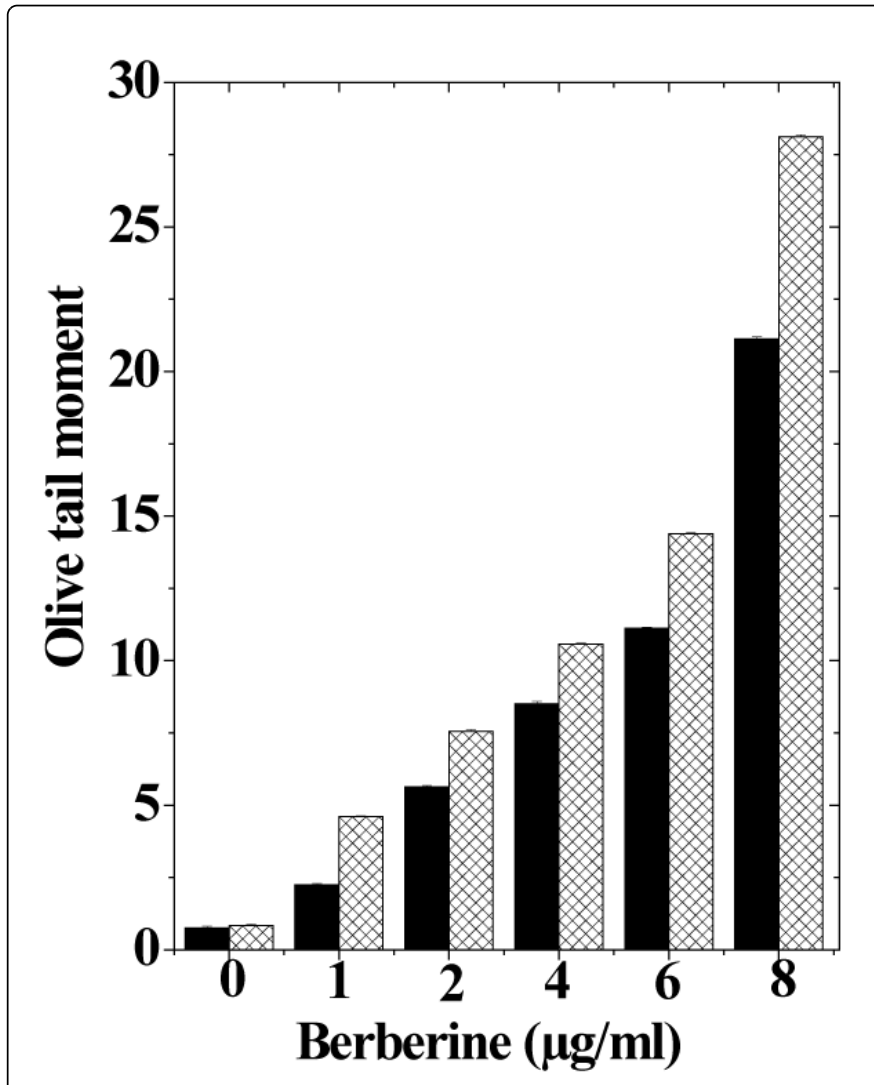

Figure 2: Effect of treatment duration on the DNA damage in HeLa cells treated with various concentrations of berberine chloride for 2 $\mathrm{h}$ (solid bars) and $4 \mathrm{~h}$ (checkered bars).

\section{Effect on DNA damage and repair}

An approximately 10 -fold increase in baseline DNA damage was observed in HeLa cells treated with $1 \mu \mathrm{g} / \mathrm{ml}$ BCL. This DNA damage was significantly higher when compared with the baseline DNA damage at all the post-BCL treatment times (Figure 3). 


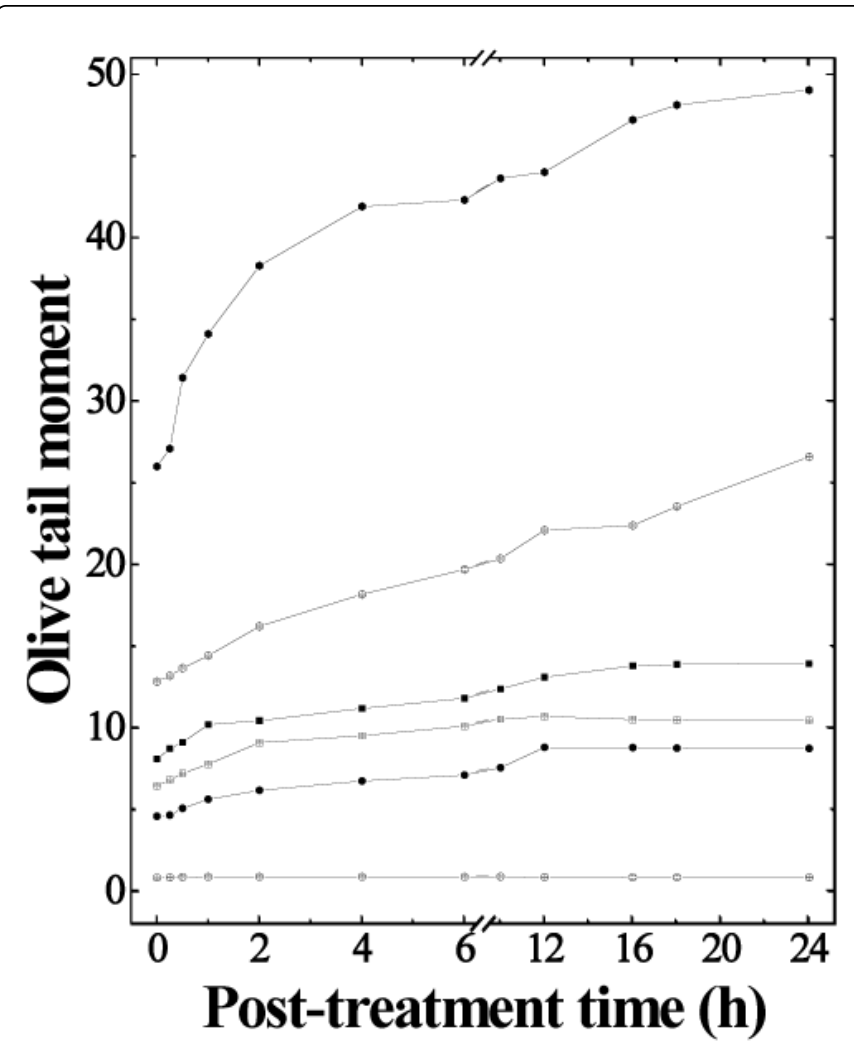

Figure 3: Effect of various concentrations of berberine chloride on the induction of DNA damage in HeLa cells at different posttreatment times. Open circles: MEM; Closed circles: $1 \mu \mathrm{g}$ BCL; Open squares: $2 \mu \mathrm{g}$ BCL; Closed Squares: $4 \mu \mathrm{g}$ BCL; Open hexagon: $6 \mu \mathrm{g}$ BCL and Closed hexagon: $8 \mu \mathrm{g}$ BCL.

Evaluation of DNA damage after treatment with various doses of BCL showed a continuous elevation up to $24 \mathrm{~h}$, except for 1 and 4 $\mu \mathrm{g} / \mathrm{ml}$, where a greatest elevation in the DNA damage was observed at $12 \mathrm{~h}$ post BCL treatment (Figure 3). A non-significant decline in DNA damage was seen at $12 \mathrm{~h}$ post-BCL treatment that became gradually significant $(\mathrm{p}<0.001)$ at $24 \mathrm{~h}$ post-treatment for all BCL doses indicating some repair of DNA damage, except for the $8 \mu \mathrm{g} / \mathrm{ml} \mathrm{BCL}$, where the maximum DNA damage was recorded at $18 \mathrm{~h}$ post-BCL treatment (Figure 3).

\section{Effect on cell survival}

Treatment of HeLa cells with various concentrations of BCL resulted in a concentration dependent decline in the clonogenicity of cells as evidenced by a continuous decline in the cell survival with a lowest survival of 0.41 for $8 \mu \mathrm{g} / \mathrm{ml}$ (Figure 4). The IC50 was found to be approximately $6.4 \mu \mathrm{g} / \mathrm{ml}$. The cytotoxicity of BCL was approximately 1.4, 1.8 and 2 folds greater than that of MEM group for 4,6 and $8 \mu \mathrm{g} / \mathrm{ml}$, respectively.

\section{Biological response}

An attempt was made to correlate the cell survival with DNA damage induced by different concentrations of BCL. The increasing DNA damage resulted in a corresponding reduction in the cell survival indicating an inverse correlation between the cell survival and DNA damage. This relationship between cell survival and DNA damage was linear quadratic (Figure 5).

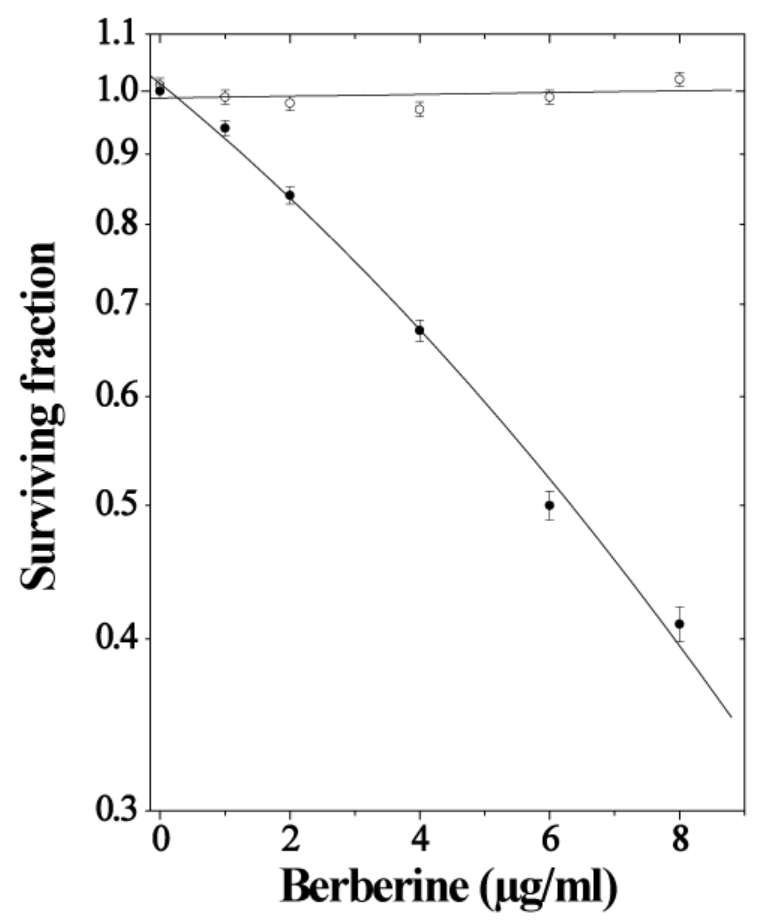

Figure 4: Alteration in the cell survival of clonogenicity cells treated with various concentrations of berberine chloride. Open circles: MEM and Closed circles: berberine chloride.

\section{Discussion}

Plant derived products have been used for human healthcare since the advent of human history. They are widely accepted as remedies by humans due to the popular belief that they arenontoxic or have few adverse side effects. The investigation of the potential beneficial or adverse effects of phytoceuticals used extensively for healthcare is of crucial importance for their safe human use. The tumor response to anticancer agents can be determined precisely using the single-cell gel electrophoresis or 'comet' assay technique for DNA damage estimation rapidly [5]. In principle, this assay could be applied to any accessible tumor being treated with chemotherapeutic agents that cause overt DNA damage. Therefore, an attempt has been made to evaluate the molecular DNA damage induced by berberine chloride in HeLa cells by comet assay and its relationship with cytotoxicity.

The DNA damage has been reported to play a pivotal role in the carcinogenesis and cell death depending on the severity of DNA damage. The greater amount of DNA damage is the hallmark of cell death as it impairs many genes and vital functions of cells [30]. This indicates that study of DNA damage is of vital importance to understand the cytotoxic effects of any physical or chemical agent. The comet assay gives precise information about the DNA damage including DNA single and double strand breaks, alkali labile sites, incomplete DNA excision repair sites [5]. The modification of comet 
assay protocol also allows the detection of DNA-DNA cross links and DNA-protein cross links [31,32].

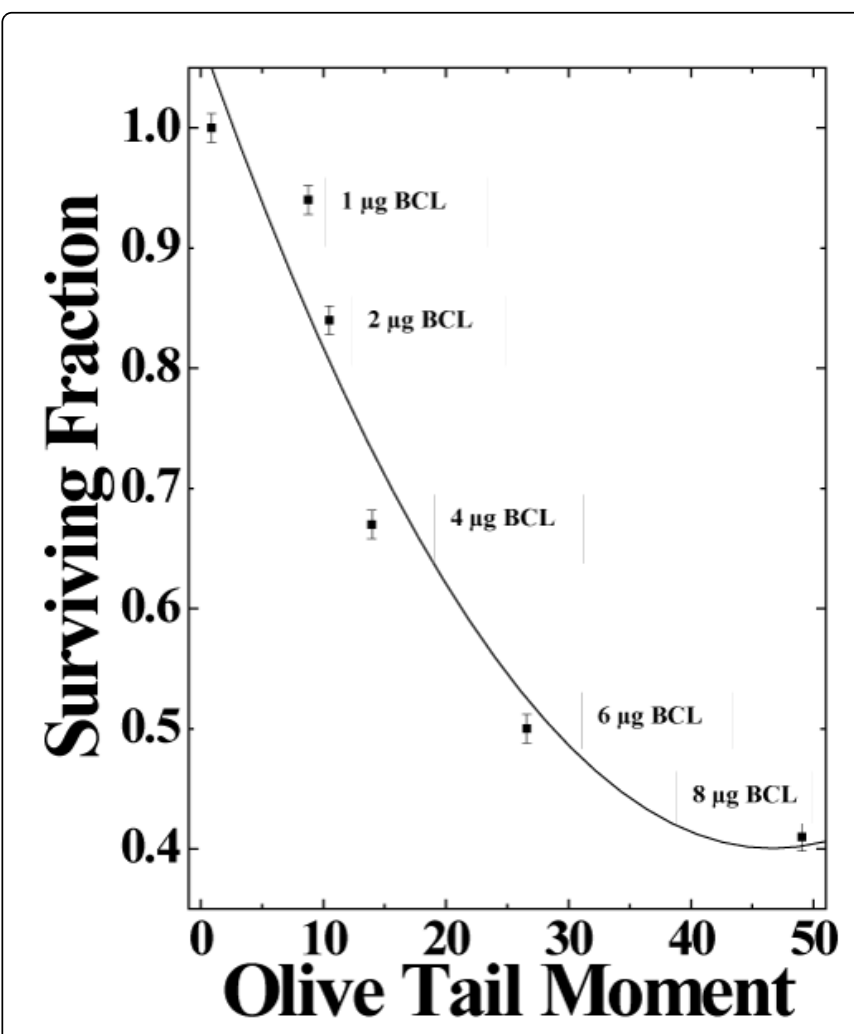

Figure 5: Correlation of DNA damage with the cell survival in HeLa cells treated with different concentrations of berberine chloride.

The comet assay measures DNA fragmentation in the cells subjected to electric field, which allows increased migration of DNA fragments from the nucleus (comet head) into the comet tails. The increased DNA fragmentation is associated with cell the death processes such as apoptosis and/or necrotic $[5,32,33]$. The increased cytotoxic effect of berberine chloride in the present study may be due to its ability to induce DNA fragmentation, which has subsequently translated into cell death. Berberine chloride has been reported to interfere with in vitro production of nucleic acids, residual proteins, and lipids, and the oxidation of glucose in mouse sarcoma-180 ascites cells [34].

The estimation of DNA damage by comet assay has revealed a concentration dependent rise in molecular DNA damage and a maximum DNA damage was discerned in cells treated with BCL for 4 $\mathrm{h}$ duration and this time was chosen for all the studies. The increased DNA migration in HeLa cells observed after $4 \mathrm{~h}$ BCL treatment maybe likely a sum of genotoxicity and cytotoxicity induced by BCL. Similarly, use of a mushroom Agaricus blazei in diethyl nitrosamineinduced hepatic carcinogenesis in rats has been found to increase DNA damage up to $4 \mathrm{~h}$ post-treatment [35]. Potassium bromide has been reported to induce DNA strand breaks in the small intestine of rats at various post-treatment times and a maximum damage was reported at $48 \mathrm{~h}$ post treatment [31].

Clonogenic assay is the gold standard to assess the cell survival and as a result it is able to determine the cytotoxicity precisely [36]. BCL treatment showed a concentration dependent decline in the cell survival due to an increase in the DNA damage in the present study. A concentration dependent decline in the cell survival has been observed in various prostate cancer cells treated with berberine [37]. A similar effect has been observed earlier in SNU-5, human glioblastomaT98G and colon cancer KM12C, KM12SM and KM12L4A cells treated with berberine [38-41]. Berberine has been shown to induce DNA damage in Ehrlich ascites carcinoma cells [19].

SimilarlyTinospora cordifolia extract that contains berberine has been reported to increase the radiation-induced DNA damage in HeLa cells earlier [42]. The estimation of DNA damage by comet assay at various post-BCL treatment times in HeLa cells exhibited a continuous and time dependent rise in the DNA damage up to $12 \mathrm{~h}$ post-BCL treatment and a marginal but non-significant decline thereafter up to $24 \mathrm{~h}$ post-BCL treatment, especially at low BCL doses indicating that HeLa cells made unsuccessful attempts to repair the damaged DNA. This was evident from the fact that the DNA damage remained higher and never returned to the level of baseline DNA damage. In an earlier study bleomycin treatment has been reported to continuously increase the OTM without signs of repair of damaged DNA in V79 cells up to 6 $\mathrm{h}$ post-treatment [27]. Similarly, potassium bromate has been reported to increase the DNA damage in the rat intestine up to $48 \mathrm{~h}$ and decline thereafter [31].

The amount of fragmented DNA increased with increasing concentration of BCL in HeLa cells, which was evident by the higher migration of DNA fragments into comet tails from the nucleus (comet head), and thus indicating elevation in DNA damage $[5,28,29]$. This increased DNA fragmentation/damage may have been responsible for the cytotoxicity in HeLa cells exposed to BCL. Despite the fact that the DNA damage increased with assessment time, the cells tried to repair the DNA damage at low BCL concentration, especially after $12 \mathrm{~h}$ post treatment, which may be the reason for higher cell survival at low concentrations of BCL (Figure 4). A repair of DNA damage has been reported after $1 \mathrm{~h}$ post-treatment in rats treated with Agaricus blazei, and bladder cancer cell lines after irradiation earlier [35,43-45].

The DNA damage (OTM) and cell survival is inversely correlated in the present study. An identical observation has been reported earlier where increasing OTM (DNA damage) was accompanied by a corresponding decline in the cell survival [43-45]. Our earlier study demonstrated that the survival of HeLa cells treated with Tinospora cordifolia extract before irradiation and DNA damage (OTM) was inversely related [42]. Similarly, DNA damage (OTM) and cell survival have been found to be inversely correlated in V79 cells treated with bleomycin [25]. Likewise, an inverse relationship between micronuclei (indicator of DNA damage) induction and cell survival has been reported earlier [46-50].

The exact mechanism of induction of DNA damage by BCL is not known. However, it may be due to the interplay of multiple putative mechanisms. BCL may have induced reactive oxygen species (ROS) in cells leading to DNA damage by hydrolysis, oxidation and/or electrophilic attack. In fact, berberine has been reported to induce reactive oxygen species earlier [51]. Treatment of HeLa cells with BCL may have induced peroxidation of lipids that would have attacked the DNA causing excessive damage to the cellular DNA [52]. BCL has been found to increase lipid per-oxidation in cultured HeLa cells (data not shown). Berberine has been found to intercalate into the DNA, induce inter-nucleosomal DNA fragmentation and form complex with DNA. 
Topoisomerase II acts by passing an intact segment of duplex DNA through a transient double-strand break that it generates in a separate double helix [53] and inhibition of topoisomerase-II by BCL may have caused DNA damage by stabilization of this transient DNA double strand breaks leading to cytotoxicity. Berberine has been reported to inhibit topoisomerase II enzyme in vitro [54]. The other possibility of berberine-induced cell killing seems to be due to the trans activation of nuclear factor- $\kappa \mathrm{B}(\mathrm{NF}-\kappa \mathrm{B})$, and cyclo-oxygenase II, and suppression of activator protein 1 , cyclins, Akt, p53 and PARP and induction apoptosis [37,40,55-58].

\section{Conclusions}

The cytotoxic effect of BCL may be due to the induction of free radicals and lipid peroxides that induced DNA damage and loss of repair capacity of HeLa cells leading to cell death. Intercalation of BCL into the DNA, inhibition of topoisomerase-II and PARP may have caused molecular DNA damage that would have subsequently led to cell death. Transactivation of NF- $\kappa$ Bandcyclooxygenase II, and inhibition of activator protein 1, cyclins, and p53 may have also contributed in their own way to induce cytotoxicity in HeLa cells exposed to BCL in the present study.

\section{Acknowledgements}

This work was supported by a grant from the Council of Scientific and Industrial Research, Govt. of India, New Delhi, India.

\section{References}

1. Cordell GA (2011) Sustainable medicines and global health care. Planta Med 77: 1129-1138.

2. Cragg GM, Newman DJ (2013) Natural products: a continuing source of novel drug leads. BiochimBiophysActa 1830: 3670-3695.

3. Gentile JM, Rahimi S, Zwiesler J, Gentile GJ, Ferguson LR (1998) Effect of selected antimutagens on the genotoxicity of antitumor agents. Mutat Res 402: 289-298.

4. Ostling O, Johanson KJ (1984) Microelectrophoretic study of radiationinduced DNA damages in individual mammalian cells. BiochemBiophys Res Commun 123: 291-298.

5. Collins AR (2014) Measuring oxidative damage to DNA and its repair with the comet assay. BiochimBiophysActa 1840: 794-800.

6. Singh NP, McCoy MT, Tice RR, Schneider EL (1988) A simple technique for quantitation of low levels of DNA damage in individual cells. Exp Cell Res 175: 184-191.

7. Olive PL, Banáth JP (2006) The comet assay: a method to measure DNA damage in individual cells. Nat Protoc 1: 23-29.

8. Birdsall TC, KellyGS (1997) Therapeutic potential of an alkaloid found in several plants. Alternat Med Rev 2: 94-103.

9. Pitea M, Petcu P, Goina T, Preda N (1972) [Thin-layer chromatographic studies of alkaloids from Berberis vulgaris]. Planta Med 21: 177-181.

10. Sturm S, Stuppner H (1998) Analysis of isoquinoline alkaloids in medicinal plants by capillary electrophoresis-mass spectrometry. Electrophoresis 19: 3026-3032.

11. Jagetia GC, Nayak V, Vidyasagar MS (1998) Evaluation of the antineoplastic activity of guduchi (Tinosporacordifolia) in cultured HeLa cells. Cancer Lett 127: 71-82.

12. Jagetia GC, Rao SK (2006) Evaluation of Cytotoxic Effects of Dichloromethane Extract of Guduchi (TinosporacordifoliaMiers ex Hook F \& THOMS) on Cultured HeLa Cells. Evid Based Complement Alternat Med 3: 267-272.

13. Jagetia GC, Nayak V (2012) Indian Medicinal Herb Guduchi (TinosporacordifoliaMeirs) Exerts its Radiosensitizing Activity by
Accelerating Chromosome Damage in HeLa Cells Exposed to Different Doses of ?-Radiation. Med Arom Plant SciBiotechnol 6: 52-62.

14. Kaneda Y, Torii M, Tanaka T, Aikawa M (1991) In vitro effects of berberinesulphate on the growth and structure of Entamoebahistolytica, Giardia lamblia and Trichomonasvaginalis. Ann Trop Med Parasitol 85: 417-425.

15. Taylor CT, Baird AW (1995) Berberine inhibition of electrogenic ion transport in rat colon. Br J Pharmacol 116: 2667-2672.

16. Ckless K, Schlottfeldt JL, Pasqual M, Moyna P, Henriques JA, et al. (1995) Inhibition of in-vitro lymphocyte transformation by the isoquinoline alkaloid berberine. J Pharm Pharmacol 47: 1029-1031.

17. Hong Y, Hui SC, Chan TY, Hou JY (2002) Effect of berberine on regression of pressure-overload induced cardiac hypertrophy in rats. Am J Chin Med 30: 589-599.

18. Jagetia GC, Baliga MS (2004) Effect of Alstoniascholaris in enhancing the anticancer activity of berberine in the Ehrlich ascites carcinoma-bearing mice. J Med Food 7: 235-244.

19. Letasiová S,JantováS, Miko M, Ovádeková R, Horváthová M (2006) Effect of berberine on proliferation, biosynthesis of macromolecules, cell cycle and induction of intercalation with DNA, dsDNA damage and apoptosis in Ehrlich ascites carcinoma cells. J PharmPharmacol 58: 263-270.

20. Asai M, Iwata N, Yoshikawa A, Aizaki Y, Ishiura S, et al. (2007) Berberine alters the processing of Alzheimer's amyloid precursor protein to decrease Abeta secretion. BiochemBiophys Res Commun 352: 498-502.

21. Lin S, Tsai SC, Lee CC, Wang BW, Liou JY, et al. (2004) Berberine inhibits HIF-1alpha expression via enhanced proteolysis. Mol Pharmacol 66: 612-619.

22. Marin-Neto JA, Maciel BC, Secches AL, Gallo Júnior L (1988) Cardiovascular effects of berberine in patients with severe congestive heart failure. ClinCardiol 11: 253-260.

23. Yusoff M, Hamid H, Houghton P (2014) Anticholinesterase inhibitory activity of quaternary alkaloids from Tinosporacrispa. Molecules 19: 1201-1211.

24. Zhang Y, Li X, Zou D, Liu W, Yang J, et al. (2008) Treatment of type 2 diabetes and dyslipidemia with the natural plant alkaloid berberine. J ClinEndocrinolMetab 93: 2559-2565.

25. Nishino H, Kitagawa K, Fujiki H, Iwashima A (1986) Berberine sulfate inhibits tumor-promoting activity of teleocidin in two-stage carcinogenesis on mouse skin. Oncology 43: 131-134.

26. PUCK TT, MARCUS PI (1956) Action of x-rays on mammalian cells. J Exp Med 103: 653-666.

27. Jagetia A, Jagetia GC, Jha S (2007) Naringin, a grapefruit flavanone, protects V79 cells against the bleomycin-induced genotoxicity and decline in survival. J ApplToxicol 27: 122-132.

28. Fairbairn DW, Olive PL, O'Neill KL (1995) The comet assay: a comprehensive review. Mutat Res 339: 37-59.

29. Azqueta A, Collins AR (2013) The essential comet assay: a comprehensive guide to measuring DNA damage and repair. Arch Toxicol 87: 949-968.

30. Ciccia A, Elledge SJ (2010) The DNA damage response: making it safe to play with knives. Mol Cell 40: 179-204.

31. Ahmad MK, Zubair H, Mahmood R (2013) DNA damage and DNAprotein cross-linking induced in rat intestine by the water disinfection by-product potassium bromate. Chemosphere 91: 1221-1224.

32. Speit G, Vesely A, Schütz P, Linsenmeyer R, Bausinger J (2014) The low molecular weight DNA diffusion assay as an indicator of cytotoxicity for the in vitro comet assay. Mutagenesis 29: 267-277.

33. Singh NP, Stephens RE, Schneider EL (1994) Modifications of alkaline microgel electrophoresis for sensitive detection of DNA damage. Int J RadiatBiol 66: 23-28.

34. Creasey WA (1979) Biochemical effects of berberine. BiochemPharmacol 28: 1081-1084.

35. Barbisan LF, Scolastici C, Miyamoto M, Salvadori DM, Ribeiro LR, et al. (2003) Effects of crude extracts of Agaricusblazei on DNA damage and 
Citation: Jagetia GC, Rao (2015) Isoquinoline Alkaloid Berberine Exerts its Antineoplastic Activity by Inducing Molecular DNA Damage in HeLa Cells: A Comet Assay Study . Biol Med (Aligarh) 7: 223. doi:10.4172/0974-8369.1000223

Page 7 of 7

on rat liver carcinogenesis induced by diethylnitrosamine. Genet Mol Res 2: 295-308.

36. Franken NA, Rodermond HM, Stap J, Haveman J, van Bree C (2006) Clonogenic assay of cells in vitro. Nat Protoc 1: 2315-2319.

37. Mantena SK, Sharma SD, Katiyar SK (2006) Berberine, a natural product, induces G1-phase cell cycle arrest and caspase-3-dependent apoptosis in human prostate carcinoma cells. Mol Cancer Ther 5: 296-308.

38. Lin JP, Yang JS, Lee JH, Hsieh WT, Chung JG (2006) Berberine induces cell cycle arrest and apoptosis in human gastric carcinoma SNU-5 cell line. World J Gastroenterol 12: 21-28.

39. Eom KS, Hong JM, Youn MJ, So HS, Park R, et al. (2008) Berberine induces G1 arrest and apoptosis in human glioblastoma T98G cells through mitochondrial/caspases pathway. BiolPharm Bulletin 31: 558-562.

40. Choi MS, Oh JH, Kim SM, Jung HY, Yoo HS, et al. (2009) Berberine inhibits p53-dependent cell growth through induction of apoptosis of prostate cancer cells. Int J Oncol 34: 1221-1230.

41. Zhang J, Cao H, Zhang B, Cao H, Xu X, et al. (2013) Berberine potently attenuates intestinal polyps growth in ApcMin mice and familial adenomatous polyposis patients through inhibition of Wntsignalling. J Cell Mol Med17: 1484-1493.

42. Jagetia GC, Rao SK (2011) Assessment of radiation-induced DNA damage by comet assay in cultured HeLa cells treated with guduch (TinosporacordifoliaMiers) before exposure to different doses of ?radiation. Res Pharmceut Biotech 3: 93-103.

43. Moneef MA, Sherwood BT, Bowman KJ, Kockelbergh RC, Symonds RP, et al. (2003) Measurements using the alkaline comet assay predict bladder cancer cell radiosensitivity. Br J Cancer 89: 2271-2276.

44. McKeown SR, Robson T, Price ME, Ho ET, Hirst DG, et al. (2003) Potential use of the alkaline comet assay as a predictor of bladder tumour response to radiation. Br J Cancer 89: 2264-2270.

45. Dunne AL, Price ME, Mothersill C, McKeown SR, Robson T, et al. (2003) Relationship between clonogenicradiosensitivity, radiation-induced apoptosis and DNA damage/repair in human colon cancer cells. Br J Cancer 89: 2277-2283.

46. Adiga SK, Jagetia GC (1999) Effect of teniposide (VM-26) on the cell survival, micronuclei-induction and lactate dehydrogenase activity on V79 cells. Toxicology 138: 29-41.

47. Adiga SK, Jagetia GC (1999) Correlation between cell survival micronuclei-induction, and LDH activity in V79 cells treated with teniposide (VM-26) before exposure to different doses of gamma radiation. ToxicolLett 109: 31-41.

48. Jagetia GC, Adiga SK (2000) Correlation between cell survival and micronuclei formation in V79 cells treated with vindesine before exposure to different doses of gamma-radiation. Mutat Res 448: 57-68.

49. Jagetia GC, Nayak V, Vidyasagar MS (2002) Enhancement of radiation effect by Guduchi (Tinosporacordifolia) in HeLa cells. PharmaceutBiol 40: 179-188.

50. Jagetia GC, Aruna R (1999) Effect of various concentrations of acyclovir on cell survival and micronuclei induction on cultured HeLa cells. Mutat Res 446: 155-165.

51. Chen TC, Lai KC, Yang JS, Liao CL, Hsia TC, et al. (2009) Involvement of reactive oxygen species and caspase-dependent pathway in berberineinduced cell cycle arrest and apoptosis in C6 rat glioma cells. Int J Oncol 34: 1681-1690.

52. Wang AG, Xia T, Chu QL, Zhang M, Liu F, et al. (2004) Effects of fluoride on lipid peroxidation, DNA damage and apoptosis in human embryo hepatocytes. Biomed Environ Sci 17: 217-222.

53. Chen SH, Chan NL, Hsieh TS (2013) New mechanistic and functional insights into DNA topoisomerases. Annu Rev Biochem 82: 139-170.

54. Makhey D, Gatto B, Yu C, Liu A, Liu LF, et al. (1995) Protoberberine alkaloids and related Compounds as Dual Inhibitors of Mammalian Topoisomerase I and II. Med Chem Res 5: 1-12.

55. Kuo CL, Chi CW, Liu TY (2005) Modulation of apoptosis by berberine through inhibition of cyclooxygenase-2 and Mcl-1 expression in oral cancer cells. In Vivo 19: 247-252.

56. Hu JP, Nishishita K, Sakai E, Yoshida H, Kato Y, et al. (2008) Berberine inhibits RANKL-induced osteoclast formation and survival through suppressing the NF-kappaB and Akt pathways. Eur J Pharmacol 580: 70-79.

57. Pandey MK, Sung B, Kunnumakkara AB, Sethi G, Chaturvedi MM, et al. (2008) Berberine modifies cysteine 179 of IkappaBalpha kinase, suppresses nuclear factor-kappaB-regulated antiapoptotic gene products, and potentiates apoptosis. Cancer Res 68: 5370-5379.

58. Fu L, Chen W, Guo W, Wang J, Tian Y, et al. (2013) Berberine Targets

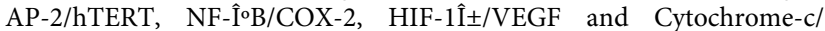
Caspase Signaling to Suppress Human Cancer Cell Growth. PLoS One 8: e69240. 